\title{
Effect of beta-blockers on arrhythmias during six weeks after suspected myocardial infarction
}

\author{
J M ROLAND， R G WILCOX， D C BANKS， B EDWARDS， P H FENTEM，J R HAMPTON
}

British Medical fournal, 1979, 2, 518-521

myocardial infarction of prophylactic antiarrhythmic agents in general, and of beta-blockers in particular, is far from clear. Immediate treatment with beta-blockers has been found both to reduce mortality, ${ }^{5}$ and to have no effect. ${ }^{6-9}$ It has been claimed that any benefit they exert is by an antiarrhythmic action, ${ }^{10}$ and Summary and conclusions

Twenty-four-hour electrocardiographic tape-recording was used to investigate the incidence of arrhythmias in patients with suspected myocardial infarction who were receiving either propranolol, atenolol, or placebo. Recordings begun within 24 hours after admission to a coronary care unit showed that $76 \%$ of patients eventually found to have had a myocardial infarction had ventricular arrhythmias of a type generally regarded as serious, whereas of patients in whom myocardial infarction was not substantiated, only $24 \%$ had such arrhythmias. At one and six weeks after admission the incidence of arrhythmias ranged from $25 \%$ to $33 \%$ irrespective of diagnosis. Of patients monitored at both one and six weeks, however, only $5 \%$ had arrhythmias on each occasion. Patients treated with propranolol and atenolol showed a similar incidence of arrhythmias to those taking placebo. There was no difference in the incidence or type of arrhythmias recorded between patients who died and those who were still alive at six weeks.

These results confirm that "serious" ventricular arrythmias occur in most patients during the acute phase of myocardial infarction and suggest that they do not constitute an independent risk factor. Beta-blockers showed little evidence of useful antiarrhythmic action in the dosage used, but increasing the dosage in suspected myocardial infarction is not practicable because of the risk of hypotension. The findings raise grave doubts about the value of studying arrhythmias to assess drugs intended to reduce mortality from myocardial infarction.

\section{Introduction}

The relation between ventricular arrhythmias and death is not clear. Although they may constitute an independent risk factor for cardiac death, they may be simply markers of heart disease rather than causes of death. Certainly they are common in apparently healthy people. ${ }^{1}$ Ventricular arrhythmias occur frequently in the acute phase of myocardial infarction and their treatment is thought to reduce mortality, ${ }^{2}$ yet patients who have cardiac arrests do not exhibit more arrhythmias than those whose course appears to be uncomplicated. ${ }^{3}+$ Similarly, the role in

\footnotetext{
Department of Therapeutics, Nottingham City Hospital, Nottingham NG5 1PB

J M ROLAND, MRCP, research fellow

D C BANKS, MD, senior lecturer

Department of Medicine, Queen's Medical Centre, Nottingham NG7 2UH

R G WILCOX, MRCP, lecturer

J R HAMPTON, FRCP, reader
}

Department of Physiology and Pharmacology, Queen's Medical Centre, Nottingham NG7 2UH

B EDWARDS, BSC, senior technician

P H FENTEM, MB, professor also that their main function is to limit the size of the infarct. ${ }^{11}$

We have used serial 24-hour electrocardiographic (ECG) recordings to investigate the incidence of arrhythmias during the six weeks after a suspected myocardial infarction and have assessed the effect on these arrhythmias of the beta-blockers propranolol and atenolol.

\section{Patients and methods}

PATIENTS

All the patients studied had been admitted to the coronary care units (CCUs) of Nottingham City Hospital and the General Hospital, Nottingham, within 24 hours after a suspected myocardial infarction. Provided they were free of haemodynamic complications (systolic blood pressure below $90 \mathrm{~mm} \mathrm{Hg}$, heart rate below 40 beats $/ \mathrm{min}$, moderate or severe heart failure, heart block), asthma, and diabetes they were entered on admission into a randomised double-blind trial comparing the effects of propranolol $40 \mathrm{mg}$ thrice daily, atenolol $50 \mathrm{mg}$ twice daily, and matching midday placebo or placebo tablets given thrice daily on morbidity and mortality during the first six weeks. Other antiarrhythmic agents were not given routinely.

On discharge from hospital the patients were assigned to one of the following diagnostic categories: (a) definite myocardial infarction-a convincing history with unequivocal changes in the ECG and serum enzyme concentrations; $(b)$ probable infarction-a convincing history with either a classical ECG or classical changes in serum enzyme concentrations; (c) possible myocardial infarction-a convincing history and an abnormal ECG that was not classical of myocardial infarction, and an increase in serum enzyme concentrations to less than twice the upper limit of normal; $(d)$ ischaemic heart diseasepatients with a history of myocardial infarction or angina whose ECGs were abnormal but in whom there were no ECG or enzyme changes to suggest a fresh event; and (e) chest pain ? cause-patients admitted with chest pain in whom no certain diagnosis was achieved. The categories "definite" and "probable" together corresponded to the WHO category of "definite infarction," and the other categories are included in the WHO category of "possible infarction."12

The clinical results of the beta-blocker study will be described separately.

\section{ECG TAPE-RECORDINGS}

A total of 388 patients were admitted to the clinical study, and 24-hour ECG recordings were made on about a quarter of these, the patients being selected at random according to the availability of tape recorders and without knowledge of their treatment group or final diagnosis. Recordings were made within 24 hours after admission to the CCU, in a medical ward at least five days after admission, and at the outpatient clinic six weeks after admission. Some patients therefore underwent recording on more than one occasion.

Tape-recordings were made with Oxford Instruments Medilog recorders and analysed visually with a Medilog DA-11 ECG analyser without knowledge of the treatment being given. Tapes were accepted for analysis only if more than eight hours of satisfactory data were obtained. All abnormal rhythms were tabulated. Ventricular arrhythmias were classified as follows, as described by Lown and Wolf. ${ }^{1:}$

"Serious" ventricular arrhythmias comprised (a) ventricular tachycardia - three or more consecutive beats of ventricular origin separated by not more than $500 \mathrm{~ms}$ (heart rate exceeding 120 beats $/ \mathrm{min}) ;(b)$ 
couplets-two consecutive ventricular beats separated by not more than $500 \mathrm{~ms}$; and $(c) \mathrm{R}$-on- $\mathrm{T}$ phenomenon-ventricular extrasystoles occurring on the $T$ wave of the preceding sinus beat, where the $R^{1}: Q T$ ratio was less than $0 \cdot 85$.

"Less serious" ventricular arrhythmias comprised (a) multiform ventricular extrasystoles-ventricular beats of substantially different waveform occurring in the same hour; $(b)$ idioventricular rhythmthree or more consecutive ventricular beats with intervals exceeding $500 \mathrm{~ms}$ (heart rate less than 120 beats $/ \mathrm{min}$ ); (c) bigeminy-alternate sinus and ventricular beats separated by a fixed interval; $(d)$ frequent ventricular extrasystoles-isolated ventricular beats occurring more frequently than 30 hour; and (e) occasional ventricular extrasystolesisolated ventricular beats occurring less frequently than $30 /$ hour.

To validate the arrhythmia-detection procedures the first hour of 55 of the tapes was analysed by inspecting the written-out ECG. "Serious" arrhythmias were detected in four of these records, and all of these had been correctly identified, as had 23 of the 26 records containing "less ser:ous" arrhythmias.

\section{HEART-RATE ANALYSIS}

Heart rates for the periods of observation were obtained with a computer. The tapes were replayed at 25 times real speed and each QRS complex converted to a standard pulse. A PDP-8 computer measured the pulse intervals and stored them on magnetic tape for analysis by the University of Nottingham's IBM 1906A computer. All intervals outside the range $333-2000 \mathrm{~ms}$ (heart rate $30-180$ beats min) were rejected as artefacts, and simple arithmetic procedures ${ }^{14}$ were used to exclude the coupling interval and compensatory pause of ectopic beats. All other intervals were included in the determination of mean heart rate. Minimum and maximum heart rates were taken from five consecutive intervals, which did not vary by more than $5 \%$.

\section{STATISTICAL ANALYSIS}

The numbers of patients with an arrhythmia in each treatment group or on each recording occasion were compared by the $\chi^{2}$ test with Yates's correction. Differences in heart rates between groups of patients were assessed by Student's $t$ test.

\section{Results}

\section{PATIENTS STUDIED}

Of the 261 tapes suitable for analysis of arrhythmias, 241 were suitable for computer analysis of heart rate, the others either having too high a noise-signal ratio or having atrial fibrillation as the predominant rhythm. The groups of patients studied in the CCU, ward, and outpatient clinic proved to be well matched for age, sex, and nature of treatment. Ninety-three patients were studied in the CCU, 76 in a medical ward, and 92 in the outpatient clinic. The mean ages of the patients in these three groups were 54,55 , and 55 years respectively; $81\left(87^{\circ}\right), 68\left(89^{\circ}{ }_{0}\right)$, and $83\left(90^{\circ}{ }_{0}\right)$ of the patients were men. Table I gives the numbers of patients on each of the three occasions

TABLE I-Numbers of patients monitored in each treatment group and final diagnostic categories

\begin{tabular}{|c|c|c|c|c|c|c|}
\hline \multicolumn{2}{|c|}{ Treatment group } & \multicolumn{2}{|r|}{ No studied } & \multirow{2}{*}{$\begin{array}{c}\begin{array}{c}\text { No with } \\
\text { definite or } \\
\text { probable MI }\end{array} \\
\text { y care unit }\end{array}$} & \multirow[t]{2}{*}{$\begin{array}{l}\text { No with } \\
\text { possible MI } \\
\text { or IHD }\end{array}$} & \multirow[t]{2}{*}{$\begin{array}{l}\text { No with } \\
\text { chest pain } \\
\text { ? cause }\end{array}$} \\
\hline \multicolumn{4}{|c|}{ Coronary care unit } & & & \\
\hline $\begin{array}{l}\text { Placebo } \ldots \\
\text { Propranolol. . } \\
\text { Atenolol .. }\end{array}$ & $\begin{array}{l}\cdots \\
\cdots\end{array}$ & $\begin{array}{l}\ldots \\
\cdots \\
\cdots\end{array}$ & $\begin{array}{l}31 \\
34 \\
28\end{array}$ & $\begin{array}{l}16 \\
24 \\
15\end{array}$ & $\begin{array}{l}7 \\
7 \\
7\end{array}$ & $\begin{array}{l}8 \\
3 \\
6\end{array}$ \\
\hline \multicolumn{7}{|c|}{ Medical ward } \\
\hline $\begin{array}{l}\text { Placebo } \ldots \\
\text { Propranolol. . } \\
\text { Atenolol .. }\end{array}$ & $\begin{array}{l}\cdots \\
\cdots \\
\cdots\end{array}$ & $\begin{array}{l}\ldots \\
\cdots \\
\cdots\end{array}$ & $\begin{array}{l}25 \\
27 \\
24\end{array}$ & $\begin{array}{l}17 \\
16 \\
16\end{array}$ & $\begin{array}{l}4 \\
9 \\
6\end{array}$ & $\begin{array}{l}4 \\
2 \\
2\end{array}$ \\
\hline \multicolumn{7}{|c|}{ Outpatient clinic } \\
\hline $\begin{array}{l}\text { Placebo ... } \\
\text { Propranolol . } \\
\text { Atenolol ... }\end{array}$ & $\begin{array}{l}\cdots \\
\cdots \\
\cdots\end{array}$ & $\begin{array}{l}\ldots \\
\cdots \\
\cdots\end{array}$ & $\begin{array}{l}30 \\
33 \\
29\end{array}$ & $\begin{array}{l}19 \\
21 \\
20\end{array}$ & $\begin{array}{r}5 \\
10 \\
7\end{array}$ & $\begin{array}{l}6 \\
2 \\
2\end{array}$ \\
\hline
\end{tabular}

$\mathrm{MI}=$ Myocardial infarction. $\mathrm{IHD}=$ Ischaemic heart disease. when recordings were made who were receiving placebo, propranolol, or atenolol and the final diagnostic category in each treatment group.

The mean interval between the onset of symptoms and the beginning of recording in the CCU was 17 hours for patients receiving placebo and atenolol and 18 hours for patients receiving propranolol. The mean intervals between giving the first trial tablet and beginning the recording were 8,11 , and 10 hours respectively for patients taking placebo, propranolol, and atenolol. Two patients in each treatment group received lignocaine infusions at some stage during the recording, and two patients taking propranolol were given atropine; no other antiarrhythmic drugs were used while the recordings were being made. The mean interval between admission and recording in the medical ward was 7.0 days for patients given placebo, 6.5 days for those given propranolol, and $6 \cdot 2$ days for those given atenolol.

\section{HEART RATES}

Table II shows the maximum, minimum, and mean heart rates recorded in each treatment group in the CCU, ward, and outpatient clinic. There was no significant difference between propranolol and atenolol, but both drugs significantly reduced the maximum heart rates when compared with placebo. Neither drug significantly affected the minimum heart rate. Eight patients taking placebo, but none taking a beta-blocker, had maximum heart rates recorded in the outpatient clinic exceeding 150 beats $/ \mathrm{min}$. In 27 patients (six taking placebo, nine propranolol, and 12 atenolol) minimum heart rates below 40 beats $/ \mathrm{min}$ were recorded.

From these results we conclude that the patients taking betablockers were receiving a dose that was effective in reducing heart rate, and that in this respect at least propranolol and atenolol were equipotent in the doses used.

TABLE II-Mean heart rates (beats/min) $\pm S E$ recorded in the three treatment groups

\begin{tabular}{|c|c|c|c|c|c|}
\hline \multicolumn{3}{|c|}{ Treatment group } & \multirow{2}{*}{\multicolumn{2}{|c|}{$\begin{array}{l}\text { Maximum Minimum } \\
\text { Coronary care unit }\end{array}$}} & \multirow[t]{2}{*}{ Mean } \\
\hline & & & & & \\
\hline $\begin{array}{l}\text { Placebo } \ldots \\
\text { Propranolol.. } \\
\text { Atenolol } \quad .\end{array}$ & $\begin{array}{l}\cdots \\
\cdots\end{array}$ & $\begin{array}{l}\cdots \\
\cdots \\
\cdots\end{array}$ & $\begin{array}{l}112 \pm 4 \\
94 \div 3 * * \\
96 \pm 3^{* *}\end{array}$ & $\begin{array}{l}51 \pm 2 \\
50 \pm 2 \\
47 \pm 2\end{array}$ & $\begin{array}{l}72 \pm 2 \\
67 \pm 2 \\
65 \pm 2\end{array}$ \\
\hline \multicolumn{6}{|c|}{ Medical ward } \\
\hline $\begin{array}{l}\text { Placebo } \ldots \\
\text { Propranolol.. } \\
\text { Atenolol } \quad .\end{array}$ & $\begin{array}{l}\cdots \\
\cdots\end{array}$ & $\begin{array}{l}\cdots \\
\cdots \\
\cdots\end{array}$ & $\begin{array}{rl}112 & 3 \\
92 & 2 * * * \\
92 & 3^{* * *}\end{array}$ & $\begin{array}{l}54 \pm 2 \\
50 \pm 2 \\
47 \pm 2\end{array}$ & $\begin{array}{l}75 \pm 3 \\
67 \pm 2 * \\
64: 2 *\end{array}$ \\
\hline \multicolumn{6}{|c|}{ Outpatient clinic } \\
\hline $\begin{array}{l}\text { Placebo } . . \\
\text { Propranolol. } \\
\text { Atenolol .. }\end{array}$ & $\begin{array}{l}\cdots \\
\cdots \\
\cdots\end{array}$ & $\begin{array}{l}\cdots \\
\cdots \\
\cdots\end{array}$ & $\begin{array}{l}134: 3 \\
109: 3^{* * *} \\
102: 3^{* * *}\end{array}$ & $\begin{array}{l}49: 1 \\
47: 1 \\
46: 1\end{array}$ & $\begin{array}{l}79 \pm 2 \\
68 \pm 2 * * * \\
65 \pm 2 * * *\end{array}$ \\
\hline
\end{tabular}

Significance compared with placebo: ${ }^{*} P .0 .02 ;{ }^{* * P}<0.01 ; * * * P<0.001$

\section{INCIDENCE OF SERIOUS ARRHYTHMIAS}

Table III gives the numbers of patients in whom serious ventricular arrhythmias (couplets, ventricular tachycardia, and R-on-T ventricular extrasystoles) were recorded. Forty-two out of 55 patients $\left(76^{\circ}\right.$ o $)$ eventually shown to have had a definite or probable myocardial infarction had such arrhythmias in the CCU, but the incidence fell to $27 \%$ in the medical ward and $33 \%$ in outpatient clinic. Among patients not shown to have had a definite or probable infarction the incidences of serious arrhythmias were $24 \%, 30 \%$, and $25 \%$ on the three occasions when recordings were made.

TABLE III-Numbers of patients with serious arrhythmias recorded in coronary care unit, medical ward, and outpatient clinic

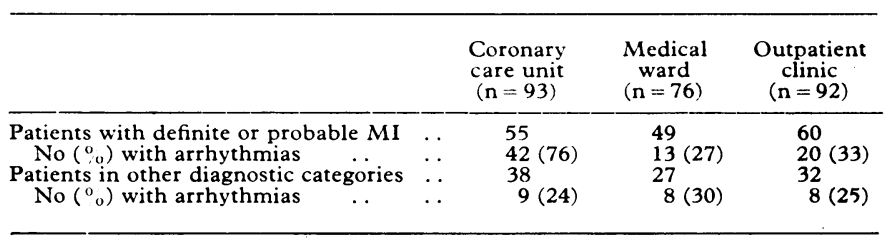

$M I=$ Myocardial infarction 
Table IV shows the occurrence of serious arrhythmias in the 39 patients on whom recordings were made in both the CCU and ward. The proportions of patients with these arrhythmias were closely similar to those detected from the single recordings shown in table III. It was therefore unlikely that significant bias occurred in recruiting patients for recording in the ward.

Out of 43 patients who had both ward and outpatient recordings, $12(28 \%)$ were found to have serious arrhythmias in the ward, and 12 had such arrhythmias in the outpatient clinic (table V). In only two cases $(5 \%)$, however, were these arrhythmias detected on both occasions. Thus during 48 hours of recording 22 of the 43 patients $(51 \%)$ had serious arrhythmias. In addition to these, 42 patients $(98 \%)$ had some sort of less serious ventricular arrhythmia in at least one recording and $39(91 \%)$ had either frequent or multiform ventricular extrasystoles, bigeminy, or idioventricular rhythm.

TABLE IV-Numbers of patients with serious arrhythmias who were monitored in both coronary care unit and medical ward (percentages in parentheses)

\begin{tabular}{|c|c|c|c|c|}
\hline & & & $\begin{array}{l}\text { Patients with } \\
\text { definite or } \\
\text { probable MI } \\
(\mathrm{n}=26)\end{array}$ & $\begin{array}{c}\text { Patients in } \\
\text { other diagnostic } \\
\text { categories } \\
(n=13)\end{array}$ \\
\hline $\begin{array}{l}\text { Coronary care unit } \\
\text { Medical ward } \ldots \\
\text { Coronary care unit and ward }\end{array}$ & $\begin{array}{l}\cdots \\
\cdots\end{array}$ & $\begin{array}{l}\ldots \\
\cdots\end{array}$ & $\begin{array}{r}19(73) \\
8(31) \\
7(27)\end{array}$ & $\begin{array}{l}4(31) \\
4(31) \\
2(15)\end{array}$ \\
\hline
\end{tabular}

$M I=$ Myocardial infarction

TABLE V-Occurrence of serious arrhythmias in 43 patients who were monitored in both medical ward and outpatient clinic (figures are numbers of patients)

\begin{tabular}{llccccc}
\hline \multicolumn{1}{c}{} & $\begin{array}{c}\text { R-on-T } \\
\text { phenomenon }\end{array}$ & $\begin{array}{c}\text { Ventricular } \\
\text { tachycardia }\end{array}$ & Couplets & $\begin{array}{c}\text { Any of } \\
\text { these }\end{array}$ \\
\hline $\begin{array}{l}\text { Medical ward } \\
\text { Outpatient clinic }\end{array}$ & $\ldots$ & $\ldots$ & 2 & 6 & 7 & 12 \\
Ward and outpatient clinic & 0 & 0 & 4 & 11 & 12 \\
\end{tabular}

\section{EFFECT OF BETA-BLOCKERS ON ARRHYTHMIAS}

It proved impracticable to analyse the number of episodes of arrhythmias recorded, for the results were too heavily biased by individual patients. In the CCU, for example, there were 49 episodes of ventricular tachycardia in patients taking placebo, but 25 of these were in a single patient; there were 220 episodes of ventricular tachycardia among patients taking propranolol, but 184 of these occurred in two patients. Thus the tape-recordings were analysed simply by the number of patients in whom one or more episodes of each arrhythmia occurred.

Table VI shows that neither beta-blocker produced a noticeable reduction in serious ventricular arrhythmias either in the CCU or subsequently. When patients with definite or probable myocardial infarction only were considered the incidence of serious arrhythmias in the CCU was $81 \%$ in the placebo group, $75 \%$ in the propranolol

TABLE VI-Numbers of recordings showing serious arrhythmias in each treatment group

\begin{tabular}{|c|c|c|c|c|c|c|}
\hline & & $\begin{array}{l}\text { No } \\
\text { of } \\
\text { records }\end{array}$ & $\begin{array}{l}\text { R-on- } \mathrm{T} \\
\text { pheno- } \\
\text { menon }\end{array}$ & $\begin{array}{l}\text { Ventri- } \\
\text { cular } \\
\text { tachy- } \\
\text { cardia }\end{array}$ & Couplets & $\begin{array}{l}\text { Any } \\
\text { of } \\
\text { these }\end{array}$ \\
\hline \multicolumn{7}{|c|}{ Placebo } \\
\hline $\begin{array}{l}\text { Coronary care unit } \\
\text { Medical ward } \\
\text { Outpatient clinic }\end{array}$ & $\begin{array}{l}\cdots \\
\cdots\end{array}$ & $\begin{array}{l}31 \\
25 \\
30\end{array}$ & $\begin{array}{l}3 \\
2 \\
2\end{array}$ & $\begin{array}{r}10 \\
2 \\
5\end{array}$ & $\begin{array}{r}13 \\
7 \\
10\end{array}$ & $\left.\begin{array}{r}15 \\
9 \\
13\end{array}\right\} 37(43)$ \\
\hline \multicolumn{7}{|c|}{ Propranolol } \\
\hline $\begin{array}{l}\text { Coronary care unit } \\
\text { Medical ward } \ldots \\
\text { Outpatient clinic }\end{array}$ & $\begin{array}{l}. \\
\cdots \\
\cdots\end{array}$ & $\begin{array}{l}34 \\
27 \\
33\end{array}$ & $\begin{array}{l}4 \\
1 \\
1\end{array}$ & $\begin{array}{r}14 \\
4 \\
2\end{array}$ & $\begin{array}{r}13 \\
6 \\
5\end{array}$ & $\left.\begin{array}{r}21 \\
8 \\
6\end{array}\right\} 35(37)$ \\
\hline \multicolumn{7}{|c|}{ Atenolol } \\
\hline $\begin{array}{l}\text { Coronary care unit } \\
\text { Medical ward } \\
\text { Outpatient clinic }\end{array}$ & $\begin{array}{l}\ldots \\
\ldots\end{array}$ & $\begin{array}{l}28 \\
24 \\
29\end{array}$ & $\begin{array}{l}2 \\
0 \\
1\end{array}$ & $\begin{array}{l}9 \\
2 \\
4\end{array}$ & $\begin{array}{r}11 \\
2 \\
9\end{array}$ & $\left.\begin{array}{r}15 \\
4 \\
9\end{array}\right\} 28(35)$ \\
\hline
\end{tabular}

group, and $73 \%$ in the atenolol group. The incidences of serious arrhythmias during the 48 hours of recording in patients monitored in both the medical ward and outpatient clinic were $50 \%, 50 \%$, and $53 \%$ for placebo, propranolol, and atenolol respectively.

Table VII gives the incidences of less serious ventricular arrhythmias. Only the reduced incidence of bigeminy associated with atenolol achieved statistical significance $(P<0 \cdot 02)$. Supraventricular ectopic beats were universal, and there was no difference in the incidence of supraventricular tachycardias between the treatment groups. Disorders of conduction were observed too rarely for useful analysis.

TABLE VII-Numbers of recordings showing less serious ventricular arrhythmias in the three treatment groups

\begin{tabular}{|c|c|c|c|c|c|c|}
\hline $\begin{array}{l}\text { Treatment } \\
\text { group }\end{array}$ & $\begin{array}{l}\text { No } \\
\text { of } \\
\text { records }\end{array}$ & $\begin{array}{l}\text { Multiform } \\
\text { ventricular } \\
\text { extra- } \\
\text { systoles }\end{array}$ & $\begin{array}{l}\text { Frequent } \\
\text { ventricular } \\
\text { extra- } \\
\text { systoles }\end{array}$ & Bigeminy & $\begin{array}{c}\text { Idioventric } \\
\text { ular } \\
\text { rhythm }\end{array}$ & $\begin{array}{l}\text { Occasional } \\
\text { - ventricular } \\
\text { extra- } \\
\text { systoles } \\
\text { only }\end{array}$ \\
\hline $\begin{array}{l}\text { Placebo ... } \\
\text { Propranolol. } \\
\text { Atenolol } \ldots\end{array}$ & $\begin{array}{l}86 \\
94 \\
81\end{array}$ & $\begin{array}{l}40 \\
48 \\
46\end{array}$ & $\begin{array}{l}27 \\
28 \\
16\end{array}$ & $\begin{array}{l}28 \\
23 \\
10\end{array}$ & $\begin{array}{r}14 \\
11 \\
7\end{array}$ & $\begin{array}{l}25 \\
24 \\
17\end{array}$ \\
\hline
\end{tabular}

DEATHS

Of the 93 patients monitored in the CCU, five died within six weeks, and three of these had had serious arrhythmias. None of the five deaths, however, was due to a primary arrhythmia. In addition, one patient, whose recording in the CCU did not show any serious arrhythmia, was resuscitated from ventricular fibrillation during his hospital admission.

\section{Discussion}

Our results confirm that ventricular arrhythmias of a type commonly regarded as serious (ventricular tachycardia, couplets, and extrasystoles showing the R-on- $T$ phenomenon) occur in most patients during the acute phase of a myocardial infarction. ${ }^{15}$ They usually pass unnoticed, even in a CCU, ${ }^{15}$ and evidently do little harm; they occur with equal frequency in patients who have a cardiac arrest and in those who do not. ${ }^{34}$

In our study the patients monitored in the CCU clearly represented a good-risk group. Only one developed ventricular fibrillation, and there were no deaths in the six weeks of followup attributable to arrhythmias. Nevertheless, $76^{\circ} \%$ of patients with myocardial infarction were found to have serious arrhythmias in the CCU. Apart from recordings made in these particular circumstances there was a remarkable consistency in the occurrence of these arrhythmias. Thus of the patients who initially showed a high incidence of arrhythmias, only $27^{\circ} \%$ and $33 \%$ were found to have these arrhythmias one and six weeks later. Among the patients who were eventually considered not to have had a myocardial infarction, $24 \%$ had serious arrhythmias in the CCU and $30^{\circ}$ and $25^{\circ}$ o had them in the ward and outpatient clinic respectively.

With the exception of the first days of infarction about $28^{\circ}$ of all our groups exhibited serious arrhythmias in 24-hour recordings. This is a closely similar result to that of Federman et $a l,,^{16}$ who reported a $26^{\circ} \%$ incidence of salvos of two or more ectopic beats and a $4 \%$ incidence of R-on- $T$ ectopic beats. If these arrhythmias were entirely random events with a $28^{\circ}$ chance of occurrence in any one 24 -hour period, we would expect that with two recordings such arrhythmias would be detected on both recordings in $8 \%$ ( $28 \%$ of $28 \%)$ of patients. In this study only $5^{\circ}{ }_{0}$ had arrhythmias in each of two recordings, which is less than would be expected by chance. Hence these arrhythmias probably do not constitute an independent risk factor. This is confirmed by our mortality figures (to be published), which like those of de Soyza $e t$ al ${ }^{17}$ suggest that patients discharged with arrhythmias do not have an adverse prognosis.

It remains possible that it is the number of times that arrhythmias occur in a single patient, and not simply their 
presence, that confers risk. It is extremely difficult to compare groups of patients because of the wide variation between individual patients, but there was nothing in our results to suggest that arrhythmias that occur often and yet do not cause haemodynamic problems are any more dangerous than those that occur only occasionally.

Although our patients were taking sufficient doses of propranolol and atenolol to reduce their maximum and mean heart rates, we found little evidence that these drugs had any useful antiarrhythmic action. Beta-blockers have antiarrhythmic properties when administered acutely, and in higher doses than we used they might have a prophylactic effect. A relatively high proportion of our patients, however, suffered sufficient hypotension to necessitate withdrawal from treatment, and we do not believe that in suspected acute myocardial infarction it is practicable routinely to give more than $40 \mathrm{mg}$ propranolol thrice daily or $50 \mathrm{mg}$ atenolol twice daily.

Even if beta-blockers have little antiarrhythmic effect in suspected myocardial infarction they may still reduce mortality by some other means. Beta-blockers are known, for example, to influence platelet behaviour ${ }^{18}$ and may limit infarct size. ${ }^{11}$

Our findings raise grave doubts about the value of studying arrhythmias to assess drugs intended to reduce mortality from myocardial infarction. Only clinical trials with death as an endpoint show the value of a drug; once a drug has been found to be effective then studies such as the one we have described may be needed to elucidate its mode of action.
We thank Professor J R A Mitchell for helpful advice and criticism, the physicians at Nottingham City Hospital and the General Hospital, Nottingham, for allowing us to study their patients, and the ECG technicians at these hospitals for invaluable work. The study was supported by a research grant from Imperial Chemical Industries Limited.

\section{References}

1 Clarke, J M, et al, Lancet, 1976, 2, 508

${ }^{2}$ Lown, B, et al, fournal of the American Medical Association, 1967, 199, 188.

${ }^{3}$ Lie, K I, et al, Circulation, 1975, 52, 755.

4 El-Sherif, N, et al, British Heart fournal, 1976, 38, 415.

5 Snow, P J D, Lancet, 1966, 2, 551.

${ }^{6}$ Balcon, $\mathrm{R}$, et al, Lancet, 1966, 2, 917.

7 Clausen, J, et al, Lancet, 1966, 2, 920.

8 Norris, R M, Caughey, D E, and Scott, P J, British Medical fournal, 1968 2, 398.

${ }^{9}$ Briant, R B, and Norris, R M, New Zealand Medical fournal, 1970, 71, 135.

${ }^{10}$ Multicentre International Study, British Medical fournal, 1975, 3, 735.

11 Norris, R M, et al, Lancet, 1978, 2, 907.

12 World Health Organisation, Regional Office for Europe, Myocardial Infarction Community Registers, p 160. Copenhagen, WHO, 1977.

${ }^{13}$ Lown, B, and Wolf, M, Circulation, 1971, 44, 130.

${ }^{14}$ Fentem, P H, et al, European fournal of Cardiology, 1977, 5, 29.

15 Romhilt, D W, et al, American fournal of Cardiology, 1973, 31, 457.

${ }^{16}$ Federman, J, et al, British Heart fournal, 1978, 40, 1243.

17 de Soyza, N, et al, American fournal of Medicine, 1978, 64, 377.

18 Frishman, W H, et al, Circulation, 1974, 50, 887.

(Accepted 12 fuly 1979)

\title{
Decreased serum 24,25-dihydroxy vitamin $D$ concentrations in children receiving chronic anticonvulsant therapy
}

\author{
Y WEISMAN, A FATTAL, Z EISENBERG, S HAREL, Z SPIRER, A HARELL
}

British Medical fournal, 1979, 2, 521-523

\section{Summary and conclusions}

Serum 24,25-dihydroxy vitamin $D\left(24,25(\mathrm{OH})_{2} D\right)$ and 25-hydroxy vitamin $D$ (25-OHD) concentrations and the ratio between the two were measured in 31 Israeli children and adolescents receiving long-term treatment with phenobarbitone or phenytoin and in controls. 24,25 $(\mathrm{OH})_{2} \mathrm{D}$ concentrations were significantly depressed in the patients, although the 25-OHD concentrations were similar to those in the healthy controls. In four patients with radiological evidence of osteopenia very low serum $24,25(\mathrm{OH})_{2} \mathrm{D}$ concentrations and serum $24,25(\mathrm{OH})_{2} \mathrm{D}$ : 25-OHD ratios were recorded.

The findings suggest that $24,25(\mathrm{OH})_{2} \mathrm{D}$ deficiency may play an important part in the pathogenesis of osteomalacia in patients treated with anticonvulsant drugs and provide further indirect evidence that $24,25(\mathrm{OH})_{2} \mathrm{D}$ is important for normal bone structure.

Departments of Paediatrics and Endocrinology, MunicipalGovernmental Medical Centre, Tel-Aviv, Israel

Y WEISMAN, MD, physician

A FATTAL, MD, physician

$Z$ EISENBERG, MSC, technician

$S$ HAREL, $M D$, paediatric neurologist

Z SPIRER, $M D$, associate professor

A HARELL, MD, associate professor

\section{Introduction}

Anticonvulsant drugs, particularly phenytoin and phenobarbitone, are thought to affect calcium and vitamin D metabolism and to cause rickets or osteomalacia. ${ }^{1-5}$ The serum concentration of 25-hydroxy vitamin D (25-OHD), the major circulating metabolite of vitamin $\mathrm{D}$, is depressed in many patients receiving anticonvulsant therapy, presumably because of enhanced conversion of 25-OHD to a biologically inactive metabolite. ${ }^{6}$ None the less, the serum concentration of $1,25-$ dihydroxy vitamin $\mathrm{D}\left(1,25(\mathrm{OH})_{2} \mathrm{D}\right)$, the active metabolite of vitamin $\mathrm{D}$, is normal or increased in patients on anticonvulsant drugs. ${ }^{8}$ Administration of vitamin D or 25-OHD has been reported to correct anticonvulsant-induced osteomalacia, ${ }^{9}$ which indicates that not all the effects of vitamin $\mathrm{D}$ may be due to $1,25(\mathrm{OH})_{2} \mathrm{D}$. Indeed, recent studies show the importance of $24,25(\mathrm{OH})_{2} \mathrm{D}$, another renal metabolite of vitamin $\mathrm{D}$, in normal bone formation. ${ }^{1011}$ We have therefore measured the serum concentrations of $24,25(\mathrm{OH})_{2} \mathrm{D}$ and $25-\mathrm{OHD}$ in patients on long-term treatment with anticonvulsants and compared the values with those in healthy subjects.

\section{Patients and methods}

Serum $25-\mathrm{OHD}$ and $24,25(\mathrm{OH})_{2} \mathrm{D}$ concentrations were measured by competitive protein binding radioassays ${ }^{12}$ in 31 children and adolescents with convulsive disorders treated with phenytoin $(n=15)$ or phenobarbitone $(n=16)$ for over 12 months and in 27 age-matched healthy controls. The patients and controls ranged in age from 2 to 17 years. Neither patients nor controls had any malabsorption or 